Pesq. Vet. Bras. 35(2):160-164, fevereiro 2015

DOI: $10.1590 / S 0100-736 X 2015000200011$

\title{
Systemic acanthamoebiasis associated with canine distemper in dogs in the semiarid region of Paraíba, Brazil ${ }^{1}$
}

\author{
Maria T.S. Frade², Luiza F. de Melo $^{2}$, Clarice R.M. Pessoa², Jeann L. de Araújo ${ }^{2}$, \\ Rafael A. Fighera ${ }^{3}$, Almir P. Souza ${ }^{2}$, Francisco Uzal ${ }^{4}$ and Antonio F.M. Dantas ${ }^{2 *}$
}

\begin{abstract}
Frade M.T.S., Melo L.F., Pessoa C.R.M., Araújo J.L., Fighera R.A., Souza A.P., Uzal F. \& Dantas A.F.M. 2015. Systemic acanthamoebiasis associated with canine distemper in dogs in the semiarid region of Paraíba, Brazil. Pesquisa Veterinária Brasileira 35(2):160-164. Hospital Veterinário, Laboratório de Patologia Animal, CSTR, Universidade Federal de Campina Grande, Campus de Patos, Av. Universitária s/n, Bairro Santa Cecília, Patos, PB 58708-110, Brazil. E-mail: dantas.af@uol.com.br

Infections by free-living amoebae can cause systemic disease in animals and humans. We describe the epidemiological, clinical and pathological aspects of disseminated acanthamoebiasis associated with canine distemper in three dogs of the semiarid region of Paraíba, Northeastern Brazil. Affected dogs developed progressive neurological and respiratory signs that progressed to death within in two to 20 days. Gross lesions were irregular and with yellow-reddish nodules randomly distributed in the lungs, heart, kidneys, spleen, lymph nodes, adrenals, and intestine. One dog had foci of malacia in the parietal cortex and another one in nucleus of brain basis. Histologically, pyogranulomas with areas of necrosis and hemorrhage in all organs affected were observed, associated with myriads of intralesional amoebic trophozoites. All three cases were concomitant canine distemper, that possibly triggered immunosuppression in the dogs. The diagnosis was performed through microscopic findings of infection by free-living amoebae and confirmed Acanthamoeba sp. by immunohistochemistry.
\end{abstract}

INDEX TERMS: Acanthamoeba sp., amebiasis, opportunistic diseases, canine distemper, diseases of dogs.

RESUMO.- [Acanthamoebíase sistêmica associada a cinomose canina em cães na região semiárida da $\mathbf{P a -}$ raíba.] Infecções por amebas de vida livre podem causar doença sistêmica nos animais e no homem. Descrevem-se os aspectos epidemiológicos, clínicos e patológicos de acanthamoebíase disseminada associada com cinomose em três cães na região semiárida da Paraíba, Nordeste do Brasil. Os cães afetados desenvolveram sinais respiratórios

${ }^{1}$ Received on August 1, 2014.

Accepted for publication on January 22, 2015.

Part of the MSc Dissertation of the first author, Programa de Pós-Graduação em Medicina Veterinária, Universidade Federal de Campina Grande (UFCG), Av. Universitária s/n, Bairro Santa Cecília, Patos, PB 58708110, Brazil.

${ }^{2}$ Hospital Veterinário, Centro de Saúde e Tecnologia Rural (CSTR), UFCG, Patos, PB 58708-110. *Corresponding author: dantas.af@uol.com.br

${ }^{3}$ Laboratório de Patologia Veterinária, Departamento de Patologia, Centro de Ciências da Saúde, Universidade Federal de Santa Maria (UFSM), Av. Roraima 1000, Camobi, Santa Maria, RS 97105-900, Brazil.

${ }^{4}$ California Animal Health and Food Safety Laboratory, University of California, Davis, San Bernardino, California, USA. e neurológicos progressivos, que evoluíram para a morte em dois a 20 dias. Na necropsia havia áreas nodulares, irregulares e amarelo-avermelhadas distribuídas aleatoriamente em pulmões, coração, rins, fígado, baço, linfonodos, adrenal e intestino. Em um caso havia foco de malácia no córtex parietal e outro em núcleo da base encefálica. Histologicamente, foram observados piogranulomas com áreas de necrose e hemorragia em todos os órgãos afetados, associados a miríades de amebas intralesionais. Nos três casos havia cinomose concomitante, que possivelmente desencadeou imunossupressão nos cães. 0 diagnóstico foi realizado através dos achados microscópicos de infecção por amebas de vida livre e confirmado Acanthamoeba sp. pela imuno-histoquímica.

TERMOS DE INDEXAÇÃO: Acanthamoeba sp., amebíase, doenças oportunistas, cinomose, doenças de cães.

\section{INTRODUCTION}

Free living amoebae, including the genera Naegleria, Acanthamoeba and Balamuthia, have been described in recent 
years causing infections in humans and animals (Martinez \& Visvesvara 1997, Visvesvara et al. 2007). These ubiquitous protozoa are found in soil, water and air in various regions of the world and have been incriminated as a cause of clinical disease in ruminants (Van der Lugt \& Van der Merwe 1990, Morales et al. 2006, Pimentel et al. 2012), horses (Kinde et al. 2007), dogs (Ayers et al. 1972, Foreman et al. 2004, Kent et al. 2011) and wildlife (Lozano-Alarcón et al. 1997). In dogs, cases of infections by Acanthamoeba spp. and Balamuthia mandrillaris have been reported in Vietnam and several regions of the United States (Ayers et al. 1972, Pearce et al. 1985, Bauer et al. 1993, Foreman et al. 2004, Dubey et al. 2005, Reed et al. 2010, Kent et al. 2011). Such infections showed acute or chronic systemic involvement mainly characterized by granulomatous inflammation associated with necrosis and hemorrhage in the lungs, heart, kidneys and brain. Up to date just one case of Naegleria fowleri infection was diagnosed in a cow in the semiarid region (Pimentel et al. 2012).

This study aimed to describe the epidemiological, clinical and pathological characteristics of three cases of systemic infection caused by Acanthamoeba sp. associated with canine distemper in dogs in the semiarid region of Paraíba, Northeastern Brazil.

\section{MATERIALS AND METHODS}

Over a period of two years (2011-2012), 281 dogs were referred to the Animal Pathology Laboratory, Veterinary Hospital, Federal University of Campina Grande (UFCG), Patos, Paraíba, Brazil, for routine necropsy. From these were selected three cases that were suggestive of infection by free-living amoebae associated with canine distemper. Fragments of various organs were collected, fixed in $10 \%$ tamponed formol and processed for histopathological examination and stained with hematoxylin and eosin. The brain and spinal cord were fixed and processed in the same way.

Paraffin blocks containing fragments of organs (lung, heart and brain [Case 1], lung [Case 2] and kidney [Case 3]) were processed for immunohistochemistry for Acantamoeba sp., $B a$ lamuthia sp., and Naegleria sp. as previously described (Daft et al. 2005) in California Animal Health and Food Safety Laboratory, University of California, Davis, San Bernardino, California, United States.

Briefly, four-micron-thick sections were treated with pepsin and horse serum for antigen retrieval and blocking, respectively. This was followed by incubation with polyclonal anti-Balamuthia, Acanthamoeba and Naegleria rabbit serum as primary antibodies. Then the avidin-biotin-peroxidase technique was used followed by a chromogen. Sections known to contain the above amoebae served as positive controls. Negative controls consisted of identical sections using diluted normal rabbit serum as primary antibody.

Immunohistochemistry was also performed in fragments of stomach of the three cases for confirmation of canine distemper virus infection in Veterinary Pathology Laboratory, Department of Pathology, Federal University of Santa Maria (UFSM), Santa Maria, Rio Grande do Sul, Brazil. Briefly, four-micron-thick sections were treated with heat and pig serum for antigen retrieval and blocking, respectively. This was followed by incubation with monoclonal anti-Canine Distemper rabbit serum as primary antibody. Then the alkaline phosphatase streptavidin-biotin technique was used, followed by a chromogen. Sections known to contain the above canine distemper virus served as positive controls. $\mathrm{Ne}-$ gative controls consisted of identical sections using diluted normal rabbit serum as primary antibody.

\section{RESULTS}

The three dogs in this study were from the city of Patos, located in the semiarid region of Paraíba, Northeast Brazil. They lived in backyards and had access the streets. The epidemiology, clinical signs and evolution meet in Table 1.

In Cases 1 and 3 dogs were neighborhood with poor sanitation, with the presence of open sewers. Only one dog (Case 3) had been vaccinated against canine distemper, but it was not revaccinated annually.

Gross lesions were disseminated in organs of thoracic and abdominal cavities. In all cases there was involvement of the lungs, heart, liver and kidneys. In two dogs there were lesions in the spleen, lymph nodes, adrenal and brain, and in one lesions were observed on the serosal surface of the small intestine. Grossly, the lesions observed in these organs were predominant granulomatous nodules associated necrosis and hemorrhage.

In Case 1, the lungs did not collapsed and bright-red with multifocal to coalescing discretely elevated yellowish nodules and surrounded by red and irregular rim; these nodules were distributed throughout the lungs and could be observed both on the pleural surface and on the cut section. Areas with similar appearance were also observed in liver, spleen, heart, kidneys, lymph nodes, small intestine serosa and adrenal. A focal and reddish area was observed in one of gyri of the right parietal lobe of the brain.

In Case 2, similar gross lesions were observed in the lungs, heart, liver and kidneys. Areas of 0.1-0.2 cm in diameter could be seen in the epicardium of both ventricles and yellow, elevated and irregular areas could be seen in the pleural surface of the caudal lobe of the left lung which up on cutting oozed a yellow exudate.

In Case 3, the lesions were seen in the lungs, heart, liver, spleen, kidneys, adrenal, tracheobronchial and pancreatic lymph nodes, and brain. The lungs did not collapsed and had multifocal to coalescing dark red nodules, elevated 0.2-2.0 cm slightly elevated to and randomly distributed throughout the pleural surface; these lesions were hard on and deepened into the parenchyma (Fig.1A) and occasionally was centrally friable. The heart had multifocal red, irregular, centrally yellowish and slightly prominent areas on the epicardial surface of the right and left ventricles

Table 1. Epidemiological data of the dogs, clinical signs and evolution

\begin{tabular}{|c|c|c|}
\hline Case & Breed/Sex/Age & Clinical signs \\
\hline $\begin{array}{c}1 \\
\text { August } 2011\end{array}$ & $\begin{array}{l}\text { Dachshund, } \\
\text { male, } \\
1 \text { year }\end{array}$ & $\begin{array}{l}\text { Apathy, persistent cough, diarrhea, } \\
\text { vomiting, dehydration and weight } \\
\text { loss, progressing to death in } 20 \text { days }\end{array}$ \\
\hline $\begin{array}{c}2^{\mathrm{a}} \\
\text { August } 2012\end{array}$ & $\begin{array}{l}\text { Mixed breed, } \\
\text { female, } \\
3 \text { months }\end{array}$ & $\begin{array}{l}\text { Weight loss, ocular and nasal purulent } \\
\text { bilateral discharge, abdominal } \\
\text { pustules and dehydration. }\end{array}$ \\
\hline $\begin{array}{c}3 \\
\text { October } 2012\end{array}$ & $\begin{array}{l}\text { Siberian husky, } \\
\text { male, } \\
10 \text { years }\end{array}$ & $\begin{array}{l}\text { Tetraparesy, spasticity, opisthotonus } \\
\text { and vocalization progressing } \\
\text { to death in about two days. }\end{array}$ \\
\hline
\end{tabular}

a Since it a street dog has not been possible to assess the clinical course. 

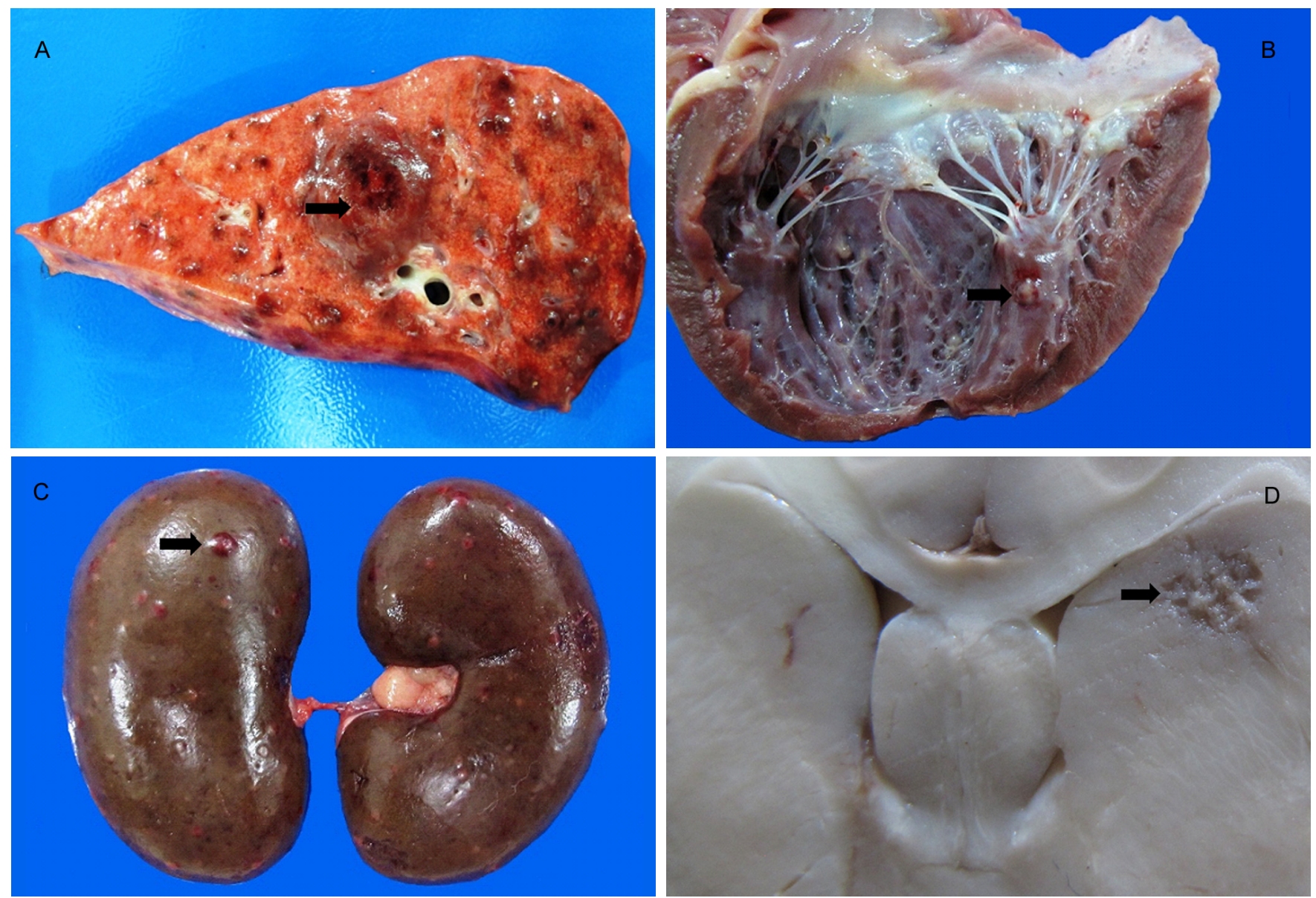

Fig.1. Macroscopic sections of lung, heart, kidney and brain with amoebic infection in dog. (A) Lung, cross-section of the pulmonary lobe showing small red-blackened multifocal and coalescing areas on the cut surface. Observe a large area discretely protruding and markedly red (arrow). (B) Heart, endocardial surface of the left ventricle and atrium. Observe the yellow-reddish nodule on the papillary muscle (arrow). (C) Kidney, yellowish areas and centrally reddish distributed randomly throughout subcapsular surface. One of this areas is larger and hemispherically protrudes (arrow). (D) Cross section of the brain after fixation, showing focal area of malacia in the right caudate nucleus (arrow).

and the left atrium. In the endocardial surface, there were $0.1-0.3 \mathrm{~cm}$ in diameter yellow nodules surrounded by red areas; they were more prominent in the papillary muscles (Fig.1B), where they deepened in the myocardium of the right and left ventricles. There was also a slightly red and irregular area in the insertion of the chordae of the left atrioventricular valve. The liver was enlarged and covered by fibrin and had an accentuated lobular pattern and multifocal to coalescing yellow irregular areas, randomly distributed throughout the capsular and cut surfaces. The kidneys were enlarged, with elevated 0.1-0.5 cm red and yellow nodules, distributed randomly beneath the subcapsular surface (Fig.1C). On the cut surface of both kidneys, these areas were deep into the whole width of the cortex. Tracheobronchial and pancreatic lymph nodes were enlarged and diffusely red with yellow and irregular areas in the cortical region and cavities containing blood. After fixation of the brain a focal $0.5 \mathrm{~cm}$ in diameter brownish area with small cavities was observed in the right caudate nucleus (Fig.1D).

Histologically, the lesions were similar in all three cases and characterized by multifocal to coalescing areas of ne- crosis and hemorrhage, surrounded by macrophages and neutrophils. Most of macrophages had a foamy cytoplasm and a most of neutrophils was degenerated. These changes varied in intensity and affected the bronchoalveolar region and alveoli, renal interstitium, the meninges, the Virchow-Robin spaces and hepatic sinusoids. In the intestine, the inflammatory infiltrate occurred from the submucosa to the serosa, sparing the lamina propria; and kidneys were mainly affected in the cortical region, especially in the periglomerular and perivascular regions; in lymph nodes occurred since the subcapsular the medullary region. In the brain of one dog (Case 1), there was granulomatous meningoencephalitis. In both cases (Case 1 and 3), there was a focal area of malacia in the right parietal lobe and right caudate nucleus, respectively, with rarefaction and cavities which contained numerous foamy macrophages (gitter cells) and neutrophils.

In all of these tissues myriads of intralesional basophilic, roughly circular structures ranging from 20 to $30 \mu \mathrm{m}$ in diameter were observed (Fig.2A); they had round and eccentric nucleus with a conspicuous karyosome surrounded by a clear halo and granular or vacuolar cytoplasm (Fig.2B), 
morphologically suggesting amoebic trophozoites. The protozoa were observed free in the interstitium or parenchyma of organs, especially in the areas of necrosis, within blood vessels, including the glomerulus (Fig.2C), in hepatic sinusoids and alveolar capillaries. They were also observed in the cytoplasm of macrophages, especially Kupffer cells (Fig.2D), in the lumen of bronchioles and forming perivascular cuffs (Fig.2E).
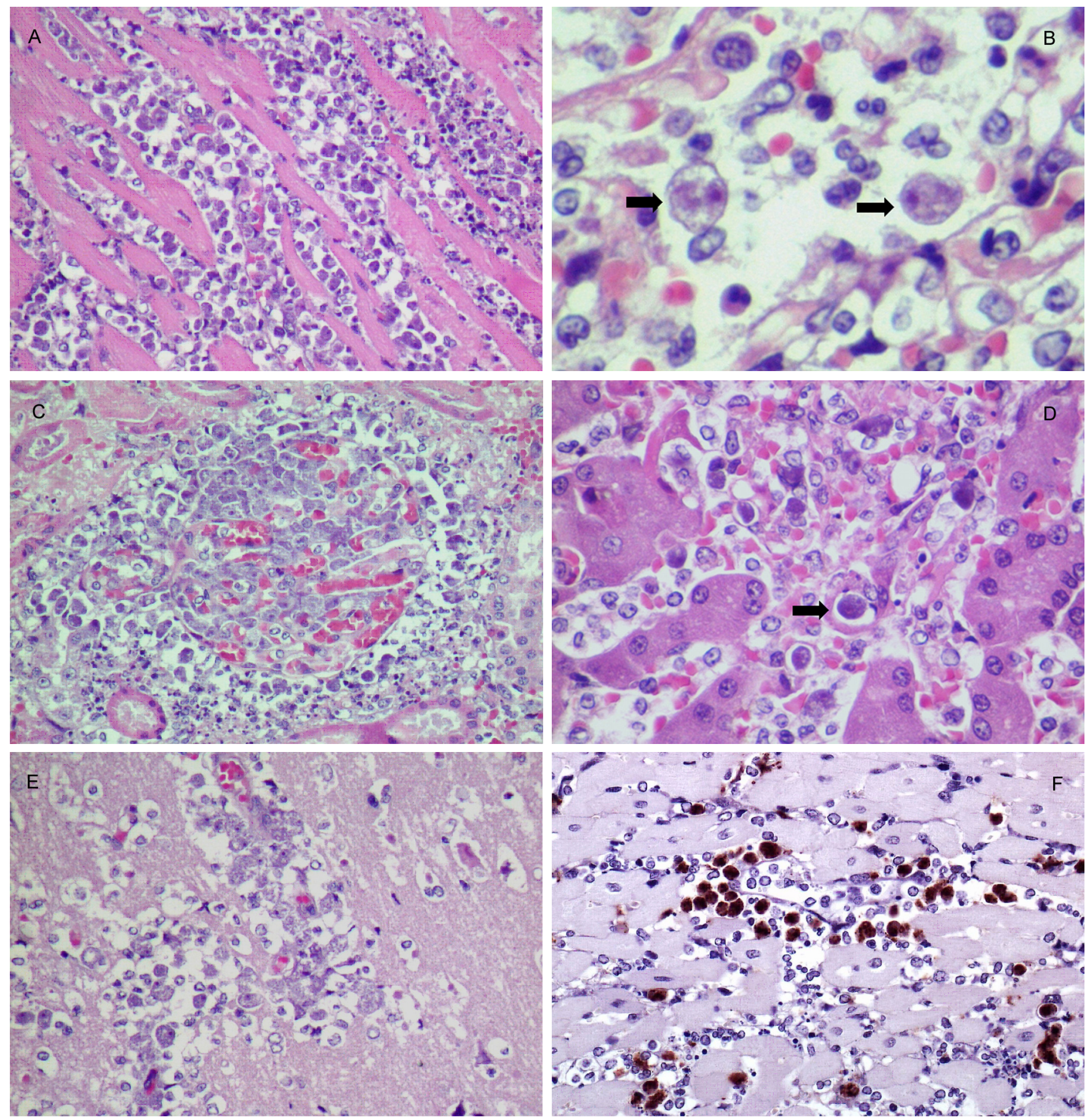

Fig.2. Histological sections of the heart, lung, kidney, liver and brain with amoebic infection in dog (Case 1). (A) Heart, inflammation, predominantly neutrophilic and histiocytic, and necrosis associated with myriad of intralesional amoebae. HE, obj.20. (B) Lung, the alveoli are filled with inflammatory cells, especially neutrophils, and trophozoites of amoebae (arrows). HE, obj.40. (C) Kidney, numerous trophozoites of amoebae within periglomerular region and the glomerular tuft. The morphology of the glomerulus is almost completely obliterated by the parasitic emboli. HE, obj.20. (D) Liver, focal area of necrosis and hemorrhage filled with trophozoites of amoeba. Observe the clear halo around one of trophozoites which is into the cytoplasm of a Kupffer cell (arrow). HE, obj.20. (E) Brain, gray matter (right parietal cortex), focal malacia and perivascular cuffs consisting of amoebae trophozoites. HE, obj.20. (F) Heart, intense staining seen in the form of round structures between inflammatory cells. These structures correspond, in histology, to amoebae trophozoites. Anti-Acantamoeba sp. immunostaining (using the streptavidin-biotin). IHC, obj.20. 
The amoebic trophozoites were strongly positive for Acantamoeba sp. (Fig.2F) and negative for Naegleria spp. and Balamuthia spp. in immunohistochemistry. Eosinophilic and intracytoplasmic viral inclusion bodies were observed mainly in the chief cells of the stomach. The viral inclusion bodies were strongly positive for canine distemper virus in immunohistochemistry.

\section{DISCUSSION}

The diagnosis of amebiasis was based on microscopic lesions associated with large amounts of trophozoites. By immunohistochemistry was possible to establish an etiologic diagnosis of Acanthamoeba sp. infection. Similar findings have been described in elsewhere (Ayers et al. 1972, Pearce et al. 1985, Bauer et al. 1993, Dubey et al. 2005, Reed et al. 2010, Kent et al. 2011).

Systemic infection by Acanthamoeba spp. is rare in dogs and is generally associated with immunosuppressive conditions such as canine distemper (Reed et al. 2010), as seen in the three cases of this report, and corticosteroid therapy (Foreman et al. 2004). However, some cases were described with absence of characteristic signs of immunosuppression (Ayers et al. 1972, Bauer et al. 1993).

In the cases of this report, the clinical signs were suggestive of distemper, affected dogs had progressive respiratory and neurological signs. The occurrence of an associated disease and nonspecific clinical signs hinders a presumptive clinical diagnosis of amebiasis. The variable clinical courses observed in these cases could be ascribed to the severity and location of the lesions, as observed in Case 3, in which the dog after running a clinical course of about two days which may be considered very short if one consider that amoebae infections present a chronic and progressive clinical course (Ayers et. al 1972, Kent et al. 2011).

The severe lesions observed in the lungs in the three cases suggest that port of entry was trough airways by inhalation of the agent, with primary pulmonary involvement and subsequent hematogenous spread to other affected organs. Similar results were also observed by Kent et al. (2011).

The recent occurrence of infection by free-living amoeba in a bovine (Pimentel et al. 2012) and dogs in the same region, demonstrates the importance of including differential diagnosis of amebiasis when examining dogs that show respiratory and progressive neurological signs or severe systemic disorders. The high temperatures observed during the warm months in the semiarid region of Northeastern Brazil may contribute to the persistence and proliferation of free-living amoebae and thus predispose to animal infections.

\section{REFERENCES}

Ayers K.H., Billups L.H. \& Garner F.M. 1972. Acanthamoebiasis in a dog. Vet. Pathol. 9:221-226.

Bauer R.W., Harrison L.R., Watson C.W., Styer E.L. \& Chapman Jr W.L. 1993. Isolation of Acanthamoeba sp. from a greyhound with pneumonia and granulomatous amebic encephalitis. J. Vet. Diagn. Invest. 5:386-391.

Daft B.M., Visvesvara G.S., Read D.H., Kinde H., Uzal F.A. \& Manzer M.D. 2005. Seasonal meningoencephalitis in Holstein cattle caused by Naegleria fowleri. J. Vet. Diagn. Invest. 17:605-609.

Dubey J.P., Benson J.E., Blakeley K.T., Booton G.C. \& Visvesvara G.S. 2005. Disseminated Acanthamoeba sp. infection in a dog. Vet. Parasitol. 128: 183-187.

Foreman O., Sykes J., Ball L., Yang N. \& De Cock H. 2004. Disseminated infection with Balamuthia mandrillaris in a dog. Vet. Pathol. 41:506-510.

Kent M., Platt S.R., Rech R.R., Eagleson J.S., Howerth E.W., Shoff M., Fuerst P.A., Booton G. \& Visvesvara G.S. 2011. Multisystemic infection with an Acanthamoeba sp. in a dog. J. Am. Vet. Med. Assoc. 238:1476-1481.

Kinde H., Read D.H., Daft B.M., Manzer M., Nordhausen R.W., Kelly D.J., Fuerst P.A., Booton G. \& Visvesvara G.S. 2007. Infections caused by pathogenic free-living amebas (Balamuthia mandrillaris and Acanthamoeba sp.) in horses. J. Vet. Diagn. Invest. 19:317-322.

Lozano-Alarcón F., Bradley G.A., Houser B.S. \& Visvesvara G.S. 1997. Primary amebic meningoencephalitis due to Naegleria fowleri in a South American Tapir. Vet. Pathol. 34:239-244.

Martinez A.J. \& Visvesvara G.S. 1997. Free-living, amphizoic and opportunistic amebas. Brain Pathol. 7:583-598.

Morales J.A., Chaves A.J., Visvesvara G.S. \& Dubey J.P. 2006. Naegleria fowleri - associated encephalitis in a cow from Costa Rica. Vet. Parasitol. 139:221-223.

Pearce J.R., Powell H.S., Chandler F.W. \& Visvesvara G.S. 1985. Amebic meningoencephalitis caused by Acanthamoeba castellani in a dog. J. Am. Vet. Med. Assoc. 187:951-952.

Pimentel L.A., Dantas A.F.M., Uzal F. \& Riet-Correa F. 2012. Meningoencephalitis caused by Naegleria fowleri in cattle of northeast Brazil. Res. Vet. Sci. 93:811-812.

Reed L.T., Miller M.A., Visvesvara G.S., Gardiner C.H., Logan M.A. \& Packer R.A. 2010. Diagnostic exercise: Cerebral mass in puppy with respiratory distress and progressive neurologic signs. Vet. Pathol. 47:11161119.

Van der Lugt J.J. \& Van der Merwe H.E. 1990. Amoebic meningoencephalitis in a sheep. J. S. Afr. Vet. Assoc. 61:33-36

Visvesvara G.S., Moura H. \& Schuster F.L. 2007. Pathogenic and opportunistic free-living amoebae: Acanthamoeba spp., Balamuthia mandrillaris, Naegleria fowleri and Sappinia diploidea. FEMS Immunol. Med. Microbiol. 50:1-26. 